\title{
The ILO and the Oldest Non-profession
}

\author{
Magaly Rodríguez García
}

In June 2010, the International Labour Organization (ILO) approved the first labor standard on HIV and AIDS in the world of work, and the ratification of Recommendation No. 200 has been hailed as a step forward by various sex workers' organizations. As activists from the Global Network of Sex Work Projects write on their webpage, sex work is not specifically mentioned in the ILO recommendation, but they refer to the discussions during the drafting process and to subsequent meetings concerning HIV to emphasize the labor approach of the Geneva organization. ${ }^{1}$ The ILO, too, stresses that the recommendation "reaches out to all workers" and highlights its community-based initiatives to train sex workers. ${ }^{2}$ The use of the term "sex worker" instead of "prostitute" in its policy papers and communication on its HIV programs is also a clear indication of the ILO's recent approach to prostitution. Sex work, however, remains in limbo in international labor law. In spite of its recognition in some national legal contexts (e.g. Germany, New Zeeland, and the Netherlands) and the increased worldwide activism of sex workers from the 1970s onward, the ILO has never advocated the legalization of prostitution.

This paper provides a historical overview of the ILO's stance toward prostitution. It argues that the ILO's refusal to put forward an international labor standard that would place sex workers on an equal footing with other workers is linked to the generalized condemnation of commercial sex, which has deep roots. Furthermore, it highlights the divisions within the ILO that make the recognition of prostitution as a form of work difficult. The analysis unfolds in two sections. In the first part, I take the reader on a conceptual tour from

* Many thanks to Dorothea Hoehtker, Liat Kozma, Richard Howard, Françoise Thébaud, and Pieter Vanhees for the provision of useful material and their helpful comments on this article.

1 "A Labour Rights Approach to HIV and Sex Work," Global Network of Sex Work Projects, accessed December 27, 2016, http://www.nswp.org/news/labour-rights-approach-hiv-and -sex-work.

2 "HIV and work. Getting to Zero through the world of work," International Labour Organization, accessed January 10, 2017, http://www.ilo.org/wcmsp5/groups/public/@ed_protect/@ protrav/@ilo_aids/documents/genericdocument/wcms_185717.pdf.

(C) MAGALY RODRÍGUEZ GARCÍA, 2018 | DOI:10.1163/9789004386617_006

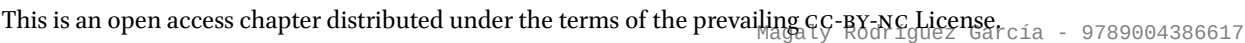


antiquity to the present, and provide some theoretical insights that might help to demonstrate why prostitution-particularly female-has been deemed problematic in most cultures. The second part focuses on the ILO's involvement with the issue, from its inception to the present day. It concentrates on three specific periods: First, from 1919 up to the 1950s, when the organization first developed its views on sexually transmitted diseases and prostitution; second, the period after the World Employment Conference of 1976, when the ILO committed to promote the status of women in developing countries; and third, recent decades, during which two special ILO programs-on HIV/AIDS and forced labor-have given impetus to the (gendered) debates on sex work. By "prostitution," I mean the provision of physical sex for payment (in cash or in kind) and I use it synonymously with "sex work" (even though the latter includes other paid services of a sexual nature, such as stripping, pornography, and telephone sex). I also use the terms "prostitute" and "sex worker" interchangeably in the text to emphasize, regarding the former, the stigma that has stuck to people (women in particular) involved in prostitution since ancient times; and for the latter, my labor approach to prostitution. My view of prostitution owes much to Marcel van der Linden's conception of "work," which he defines as "the production of useful objects and services." This broad definition of work has facilitated the entrance of a whole range of men and women into the (analytical) realm of labor. Whether society at large is prepared to treat activities such as prostitution as a form of work remains to be seen.

\section{$2 \quad$ The Meaning of Prostitution 4}

The Cambridge online dictionary defines prostitution as "the work of a prostitute," and a prostitute as "a person who has sex with someone for money."

3 Marcel van der Linden, "Studying Attitudes to Work Worldwide, 1500-1650: Concepts, Sources, and Problems of Interpretation," International Review of Social History 56 (2011), 25-43, 27.

4 The main ideas of this section are further developed in Magaly Rodríguez García, "Defining Commercial Sexualities, Past and Present," in The Routledge Research Companion to Geographies of Sex and Sexualities, eds. Gavin Browne and Kath Brown (Oxford, 2016), 321-329; Magaly Rodríguez García, "Ideas and Practices of Prostitution around the World," in The Oxford Handbook of the History of Crime and Criminal Justice, eds. Paul Knepper and Anja Johansen (New York, 2016), 132-154; Magaly Rodríguez Garcia, Elise van Nederveen Meerkerk and Lex Heerma van Voss, "Selling Sex in World Cities, 16oos-200os: An Introduction," in Selling Sex in the City: A Global History of Prostitution, 16oos-20oos, eds. Magaly Rodríguez García, Lex Heerma van Voss, and Elise van Nederveen Meerkerk (Leiden, 2017), 1-21.

5 http://dictionary.cambridge.org/dictionary/english/prostitution; http://dictionary.cambrid ge.org/dictionary/english/prostitute (27 December 2016). 
However, prostitution has rarely been considered a job like any other, especially when practiced by women. Perhaps its metaphorical definition found in the Oxford online dictionary provides a clearer clue to its symbolic meaning across time and space: Prostitution is "the unworthy or corrupt use of one's talents for personal or financial gain" (emphasis added). ${ }^{6}$ Indeed, it is the moral or status connotation attached to it, and not the service provided in the exchange of sexual favors for money or in kind, that has characterized the meaning of prostitution in many societies.

The view of prostitution as an evil - a necessary one for some and an unwarranted one for others-seems to be ubiquitous. Recently, an increasing number of historians of the ancient world have started to stress the negative perception of prostitution and to question the radical distinction between hetaira (a free prostitute working independently and in relatively good conditions) and porne $\bar{e}$ (a common prostitute of slave status and confined to a brothel). According to Allison Glazebrook, the ancients did not make a clear distinction between hetairai or pornai, or between hetairai or adulteresses and women in atypical relationships. Porne was, in any case, the more pejorative term. The word probably derives from the verb pernēmi, which means "to sell." Other ancient labels also emphasize the material nature of the prostitute-client relationship and the (female) prostitute's "innate immorality." For male prostitutes, not the noun pornoi but the verb form for prostitution, pornos, was commonly used. This suggests that for males, prostitution was simply perceived as a trade, whereas for women it was considered an identity. ${ }^{7}$ In republican and imperial Rome, the most common terms for prostitute were meretrix and scortum. Meretrix derives from mereo, meaning "to earn" or "to merit," and stresses the economic aspect of prostitution. Derivatives from the Latin meretrix are also preferred in some contemporary societies. In Bolivia, for example, prostitutes prefer to be called meretrices, as the word highlights the labor aspect of prostitution and depicts them as working women. ${ }^{8}$

In some other regions and time periods, too, prostitution has been perceived as a form of work - albeit morally condemned. Indeed, although some forms

6 https://en.oxforddictionaries.com/definition/prostitution (27 December 2016).

7 Allison Glazebrook, "The Bad Girls of Athens: The Image and Function of Hetairai in Judicial Oratory," in Prostitutes \& Courtesans in the Ancient World, eds. Christopher A. Faraone and Laura K. McClure (Madison, 2006), 125-138; Allison Glazebrook, "Prostitution," in A Cultural History of Sexuality in the Classic World, eds. Mark Golden and Peter Toohey (Oxford/New York, 2011), 145-168.

8 Pascal Absi, "The Future of an Institution from the Past: Accommodating Regulationism in Potosí (Bolivia) from the Nineteenth to Twenty-First Centuries," in Selling Sex in the City, eds. Rodríguez García, Heerma van Voss, and van Nederveen Meerkerk, 466-489. 
of high-level prostitution in earlier times commanded respect and prestige, most societies have treated prostitutes with contempt. For hundreds of years in pre-colonial India, common prostitutes formed part of the mainstream labor population but were perceived as "sinners." Furthermore, the caste-based, hierarchical society accorded them a low social status and placed them just above sweepers. ${ }^{9}$ During most of Chinese history, prostitution was legal and monitored by the imperial or local state. Within this highly patriarchal society, providing sex commercially was recognized as an occupation, but one that was meant to distinguish "good" women from those who provided social companionship and sexual services to men. ${ }^{10}$ In Cairo, prostitutes were taxed, had access to court, and were allowed to participate in guild processions-albeit marching at the end of the parade. ${ }^{11}$ In medieval Europe, municipal authorities of most large cities regulated prostitution and tolerated prostitutes because they supposedly served as outlets for male sexual drives and protected "honest" women from rape. ${ }^{12}$ Advocates of the modern system of regulation (installed in France by Napoleon) followed this Augustinian logic. ${ }^{13}$ However, the nineteenth-century system of regulation, with its enclosed brothels, compulsory registration, harsh medical treatment, confinement to specialized hospitals for the treatment of venereal diseases, or imprisonment for clandestine prostitutes, treated women as quasi criminals or, in the best case, as filthy workers. For instance, the French hygienist Alexandre Parent-Duchâtelet described prostitutes "as inevitable as sewers." 14

Moreover, comparative studies of prostitution demonstrate that some sex workers internalized this general scorn for prostitution. When a group of prostitutes demanded better working and living conditions in Buenos Aires during

$9 \quad$ Raelene Frances, "Prostitution: The Age of Empires," in A Cultural History of Sexuality in the Age of Empire, eds. Chiara Beccalossi and Ivan Crozier (Oxford, 2011), 145-170.

10 Sue Gronewold, "Prostitution in Shanghai," in Selling Sex in the City, eds. Rodríguez García, Heerma van Voss, and van Nederveen Meerkerk, 567-593.

11 Hahan Hammad and Francesca Biancani, "Prostitution in Cairo," in Selling Sex in the City, eds. Rodríguez García, Heerma van Voss, and van Nederveen Meerkerk, 234-26o.

12 Ruth Mazo Karras, Common Women:Prostitution and Sexuality in Medieval England (New York, 1996); Mary Elizabeth Perry, Gender and Disorder in Early Modern Seville (New Jersey, 1990); Richard Trexler, "La prostitution florentine au XVe siècle: patronages et clientèles," Annales. Économies, Sociétés, Civilisations 36 (1981): 983-1015.

13 The fourth-century Christian theologian Augustine of Hippo once wrote: "Suppress prostitution, and capricious lusts will overthrow society," quoted in Nicky Roberts, Whores in History: Prostitution in Western Society (London, 1992), 61.

14 Alexandre Parent-Duchâtelet, De la prostitution dans la ville de Paris, considérée sous le rapport de l'hygiène publique, de la morale et de l'administration (London/Brussels, 1838), 336. 
the 1930s, one of them told a reporter: "we have not all become what we wanted to become, but the fact is that we are workers, the worst class of workers, but we have a right to live as gente decente." ${ }^{15}$ Later on in the twentieth century, the development of the sex workers' rights movement helped to build self-esteem among the women, men, and trans people engaged in prostitution. Increasingly since the mid-1970s, confident sex workers have contributed to a multitude of (printed and online) publications and public manifestations worldwide that demand state protection and an end to discrimination. In 2015, a Dutch union for sex workers was created, calling itself "PROUD."16 However, even in countries where prostitution is legal, such as the Netherlands, the main actors (sex workers, clients, and intermediaries) continue to be stigmatized. In a recent call to demonstrate against the compulsory interviews and illegal registration of sex workers in Groningen (a city in the north of the Netherlands), PROUD activists promised to distribute red umbrellas and masks to protect the privacy of the participants. ${ }^{17}$ The red umbrella was first used by sex workers in Venice in 2001; in 2005, the International Committee on the Rights of Sex Workers in Europe adopted it as a symbol of "protection from the abuse and discrimination faced by sex workers everywhere." 18

Indeed, from antiquity to the present, the mandatory use of distinguishable clothing or ornaments and the establishment of zoning laws have served the purpose of singling out sex workers and keeping them at a safe distance from "respectable" society. The poor reputation of prostitution has deep roots. Throughout time and space, the notions used to describe commercial sex have nearly always involved the condemnation of atypical sex acts. In spite of the geographical and temporal differences in the way the sex trade has been practiced and policed, available literature demonstrates that unorthodox sexual desire has been deemed disruptive in most cultures. As it became increasingly

15 "La vida miserable y trágica de las cabareteras revelada ante varios funcionarios oficiales," El Gráfico, 19 October 1937: 12, quoted in Donna J. Guy, Sex and Danger in Buenos Aires. Prostitution, Family and Nation in Argentina (Lincoln, 1991), 200; Lex Heerma van Voss, “'The Worst Class of Workers': Migration, Labor Relations and Living Strategies of Prostitutes Around 1900," in Working on Labor: Essays in Honor of Jan Lucassen, eds. Marcel van der Linden and Leo Lucassen (Leiden, 2012), 153-170.

16 PROUD Belangenvereniging voor en door sekswerkers accessed December 28, 2016, http://wijzijnproud.nl/.

17 "Sekswerkers Groningen protesteren tegen illegale registratie," PROUD, accessed December 28, 2016, http://wijzijnproud.nl/2016/o9/05/sekswerkers-groningen-protesteren-tegen -illegale-registratie/.

18 "Under the red umbrella," International Committee on the Rights of Sex Workers in Europe, accessed December 28, 2016, http://www.sexworkeurope.org/campaigns/red -umbrella-campaigns. 
commodified with the rise of industrial societies, the growth of national armies, and increased migration, commercial sex became a constant preoccupation of the elites and the bourgeoisie. In particular, women using sex for purposes other than procreation were (and still are in many places) openly or less openly incriminated..$^{19}$ Female promiscuity has been commonly condemned in all patriarchal societies, as it threatens the ability to ascertain paternity on the part of men and, from women's point of view, to secure faithful and healthy husbands or partners. Moreover, the nexus between female licentiousness and financial or material gain exacerbates the anxiety of men regarding their traditional role as head of the family and breadwinner. In short, the "female capacity of opportunistic promiscuity threatens the very premise of the patriarchal family, and the prostitute is a constant reminder of this ability."20

The idea of the prostitute as a deviant, a threat, or an outright criminal in the nineteenth and twentieth centuries was not, however, universal. The notion of the fallen woman could refer not only to sinful or unruly behavior for which she was responsible, but also to situations of vulnerability in which women fell prey to malevolent men. From the second half of the nineteenth century, women involved in prostitution became increasingly perceived as victims in Western countries where the feminist movement gained ground. In the $\mathrm{UK}$, feminists and libertarians helped publicize a series of sexual scandals in the 1880 s, which ended with the reporting of Jack the Ripper and the murder of five prostitutes. William Stead's newspaper publication on the abduction of English girls, who were subsequently sold to continental brothels, as well as the media attention given to the Ripper murders, rendered all men suspect and strengthened the notions of urban danger and female fragility. ${ }^{21}$ The link between (migration for) prostitution, male violence, and trafficking was established at the time. By the end of the nineteenth century, a movement for the suppression of "white slave traffic" had emerged in Britain and had been disseminated internationally. From the early twentieth century onward,

19 Michel Foucault, Histoire de la sexualité: La volonté de savoir (Paris, 1976); Robert Barker, Kathleen Wininger, and Frederick Elliston, The Philosophy of Sex (New York, 1984); Nina Peršak and Gert Vermeulen, "Faces and Spaces of Prostitution," in Reframing Prostitution. From Discourse to Description, from Moralisation to Normalisation?, eds. Nina Peršak and Gert Vermeulen (Antwerp, 2014), 13-24.

20 Lena Edlund and Evelyn Korn, "A Theory of Prostitution," Journal of Political Economy 110 (2002): 181-214, here: 208.

21 Judith Walkowitz, "Jack the Ripper and the Myth of Male Violence," Feminist Studies 8 (1982): 542-574. 
national and international initiatives to curtail trafficking for prostitution rose to a crescendo. ${ }^{22}$

The perception of prostitution as a harmful activity, in which women are the main victims, has become increasingly influential since the last decades of the twentieth century. In the U.S., certain feminists view prostitution as the sexual oppression of women and demand the decriminalization ${ }^{23}$ of prostitutes as a short-term solution, and the radical transformation of the socioeconomic structure of society to eliminate prostitution in the long run. Some radical feminist writers and activists linked to networks such as the European Women's Lobby refuse to define prostitution in terms of labor. They understand prostitution as "sexual slavery," and prefer to speak of "prostituted women" instead of "prostitutes," as the former term "brings the perpetrator into the picture"24 and emphasizes, in their view, the male sexual violence involved in it. ${ }^{25}$

In Sweden, a similar logic has been applied, but with a new strategy. Focusing on the demand side of prostitution, some Swedish feminists called for the criminalization of clients. After a long debate, the purchase of sex was made illegal in Sweden in $1999 .{ }^{26}$ In that context, prostitution is viewed as a crime, but one committed by men on women. Hence the idea of women as victims and men as predators is strengthened. With some variations, the so-called Swedish model has spread to several European countries. As was the case at the turn of the nineteenth century, contemporary supporters of this interpretation of prostitution are of the opinion that commercial sex fuels human trafficking. In February 2014, the European Parliament approved a non-binding resolution, which recommends that EU countries re-evaluate their prostitution policies to reduce the demand for commercial sex and trafficking, by punishing clients. Since prostitution is seen as inherently exploitative and as a violation of human rights, supporters of the Swedish model make no distinction between voluntary and forced prostitution. In their view, women are forced into prostitution by third parties, poverty, or both, so that prostitution cannot possibly be understood as a form of work.

22 In 1921, the League of Nations replaced the racialized term "white slavery" by "traffic in women and children." Stephanie Limoncelli, The Politics of Trafficking: The First International Movement to Combat the Sexual Exploitation of Women (Stanford, 2010).

23 Advocates of decriminalization are not in favor of legalizing prostitution.

24 Sheila Jeffreys, The Idea of Prostitution (North Melbourne, 1997), 5.

25 Kathleen Barry, Female Sexual Slavery (Englewood Cliffs, 1979).

26 Yvonne Svanström, "Criminalising the John: A Swedish Gender Model," in The Politics of Prostitution: Women's Movements, Democratic States and the Globalisation of Sex Commerce, ed. Joyce Outshoorn (Cambridge, 2004), 225-244. 
The idea of "unusual" or "immoral" sexuality inherent in prostitution and the representation of prostitutes as threats or victims have not only reinforced its bad reputation, but they have also made it more difficult to study. Until recently, very few people directly involved in the sex trade left first-hand accounts of their activities and motivations. Scientific analyses containing information about the social backgrounds and the working and living conditions of prostitutes in the past are usually based on sources that originated within normative contexts such as policy making or policing of the trade. However, although difficult to find, primary sources about the people involved in prostitution do exist. Moreover, recent decades have witnessed a significant increase in the amount of personal testimonies of sex workers worldwide. Various historians, sociologists, and other social scientists are currently making great efforts to present alternative narratives of prostitution. ${ }^{27}$ Bottom-up analyses of prostitution and first-hand accounts have not, however, led to the inclusion of the views of the people concerned in policy making at the national and international levels. ${ }^{28}$

Accordingly, the problem in studying sex work is not necessarily related to a lack of sources, but to the perception of prostitution. In contrast to the analysis of other human activities, it appears that the study of prostitution is heavily influenced by emotions and personal views about sexuality and intimacy. ${ }^{29}$ This tendency has often reduced prostitution debates and policy formation to "normative claims that are presented as self-evidenced truths that need no

27 See among others: Julia Laite, Common Prostitutes and Ordinary Citizens: Commercial Sex in London, 1885-1960 (London, 2011); Julia Laite, "Traffickers and Pimps in the Era of White Slavery," Past \& Present 237 (2017): 237-269; P.G. Macioti and Giulia Garofalo Geymonat, "Sex workers speak. Who listens?" openDemocracy, last modified 2016, accessed December 28, 2016, http://www.nswp.org/sites/nswp.org/files/Sex\%2oWorkers\%2oSpeak.\%20 Who\%2oListens\%3F\%2C\%2oMacioti\%2oand\%20Geymonat\%20-\%202016.pdf.

28 The recent \#AreWeNotWomen campaign of the Global Network of Sex Work Projects "seeks to highlight how sex workers are being excluded and silenced by some of the women's movements in the development of the new UN Women sex work policy," 9 December 2016, accessed December 29, 2016, http://www.nswp.org/news/ arewenotwomen-campaign.

29 I am thankful to Jan Lucassen for bringing this point to my attention during the European Social Science History Conference, Vienna, April 2014. Hendrik Wagenaar and Sietske Altink, "Prostitution as Morality Politics or Why it is Exceedingly Difficult To Design and Sustain Effective Prostitution Policy," Sexuality Research and Social Policy 9, no. 3 (2012): 279-292. The authors argue that prostitution policy can be understood as an instance of morality politics. As such, much of prostitution policy is influenced by ideology, is emotionally charged, and is resistant to empirical evidence. 
justification or evidential explanation." ${ }^{30}$ As the following paragraphs demonstrate, personal views on prostitution also influenced the discourse and initiatives of international actors.

\section{Prostitution in Geneva}

\subsection{The Interwar Years}

The interpretations of prostitution described above are clearly discernable in ILO material. Soon after their foundation in 1919, the League of Nations and the ILO touched upon the issue but in an indirect way. Since prostitution was perceived as a matter of national authority, both organizations dealt with it through their campaigns on borderless issues: Phenomena that (allegedly) involve international criminal networks and the spread of bacteria and viruses. ${ }^{31}$ While article $23 \mathrm{c}$ of the League of Nations' Covenant entrusted the organization with monitoring the international agreements on trafficking in women and children, the preamble of the ILO's Constitution placed it in charge of the protection of workers against disease. The League also agreed on the creation of a technical committee to specifically deal with health concerns and founded in 1921 the League of Nations' Health Organization (LNHO). Venereal disease and its link with prostitution received a great deal of attention in all of these Geneva based organizations.

Concerns regarding "loose morals," the spread of sexually transmitted diseases (STDs), and physical degeneration have intensified since the modern period. A healthy labor force and army were crucial to protect the nascent nation-states and to guarantee the realization of imperialist projects. This preoccupation was reflected in the installation of systems for the regulation of prostitution in various cities in Europe and the Americas. By the end of the nineteenth century, medical authorities, the police, voluntary organizations, and others agreed that the spread of sTDs called for international analysis and response. Various initiatives took place during the first years of the new

30 Isabel Crowhurst, "Troubling Unknowns and Certainties in Prostitution Policy ClaimsMaking," in Prostitution Research in Context: Methodology, Representation and Power, eds. May-Len Skilbrei and Marlene Spanger (Oxford, 2017), 47-63.

31 Magaly Rodríguez, Davide Rodogno, and Liat Kozma, "Introduction," in The League of Nations' Work on Social Issues: Visions, Endeavours and Experiments, eds. Magaly Rodríguez, Davide Rodogno, and Liat Kozma (Geneva, 2016), 13-28, accessed December 29, 2016, http://www.un-ilibrary.org/united-nations/the-league-of-nations-work-on-social -issues_43045dc7-en. 
century. ${ }^{32}$ The experience of the First World War gave further impetus to local, national, and international action against sTDs.

Under the leadership of its energetic first secretary-general, the French socialist Albert Thomas, the ILO created its own medical division. It focused initially on sailors, whose "nomadic" and "promiscuous" life made them particularly vulnerable to infection. ${ }^{33}$ After the Genoa maritime conference of 1920 , the ILO attempted to promote itself as one of the key players in an international network for the treatment and prevention of sTDs among seamen. ${ }^{34}$ It conducted a first survey of treatment centers in ports and harbors and sponsored the International Agreement respecting Facilities to be given to Merchant Seamen for the Treatment of Venereal Diseases, signed in Brussels in 1924. The agreement was meant to guarantee free treatment to all merchant seamen or watermen without distinction. It also provided for issuing an individual but anonymous health card, which enabled the patient to continue treatment in the next port of call. Masters of ships, ship owners, and sanitary inspection officers were required to inform the crews about the treatment facilities, and times and places for consultations. ${ }^{35}$

Although the ILO had initially focused on medical treatment and the prevention of STDs, its discourse became more moralistic after the late $1920 s$. Increased cooperation with the Union Internationale contre le Péril Vénérien (UIPV) and the League's anti-traffic committee may explain this change. The UIPV was established in Paris in 1923, and was composed of state representatives, various specialist societies, and technical representatives from the LNHO, the International Council of Women, and the ILO. From 1927, it was headed by Dr. J.A. Cavaillon—a French public health official—and was strongly

32 Josep L. Barona, "The emergence of venereal diseases in the international agenda (ca. 190o)," paper presented at the European Social Science History Conference, Valencia, 30 March 2016.

33 Bureau international du travail, La protection de la santé des marins contre les maladies vénériennes. Etudes et documents, Series P. (Marins), no. 2 (Geneva, 1926), 1-2. I am extremely thankful to Liat Kozma for providing these sources and for sharing with me her views on the international policing of "men on the move."

34 Paul Weindling, "The Politics of International Co-ordination to Combat Sexually Transmitted Diseases, 1900-1980s," in AIDS and Contemporary History, eds. Virginia Berridge and Philip Strong (New York, 1993), 93-107.

35 International Agreement respecting Facilities to be given to Merchant Seamen for the Treatment of Venereal Diseases, Brussels, 1 December 1924 accessed December 29, 2016, http://treaties.fco.gov.uk/docs/fullnames/pdf/1926/TSoo20\%2o(1926)\%2oCMND-27 27\%201924\%201\%20DEC,\%20BRUSSELS\%3 B\%20AGREEMENT\%20RESPECTING\%20 FACILITIES\%2oTO\%2oBE\%20GIVEN\%2oTO\%2oMERCHANT\%2oSEAMEN\%20 FOR\%20TREATMENT\%20OF\%20VENEREAL\%2oDISEASE.pdf. 
supported by Sybil Neville-Rolfe- "the formidable Secretary-General of the [British] National Council for Combating Venereal Disease and eugenicist." ${ }^{36}$ By the early 1930s, the UIPV had tried to find a balance between the medical approach and social hygiene. Its suggestions served as an inspiration for the drafting of the 1931 report on the "Amélioration des conditions de séjour des marins dans les ports," in which the ILO recommended, among other things, the closing down of establishments that served alcohol around ports by 10 p.m., the reduction of the number of taverns, a ban on the employment of female waitresses in establishments that served alcohol, and severe medical control of women who had illegitimate relationships with men. ${ }^{37}$

Around the same time, the League's experts finalized their enquiries into international trafficking in women and children. ${ }^{38}$ They reached the conclusion that among the main causes of the global trafficking and prostitution in general were the intermediaries of prostitution and the regulation system. ${ }^{39}$ This allowed them to go beyond their competence and to call for the abolition of the system which, they argued, maintained women in "a position of terrible slavery." ${ }^{40}$ During the anti-traffic committee's meetings of the 1930s, its members no longer discussed trafficking, but turned their attention to the relationship between women's low wages, unemployment, and prostitution, the best means to rehabilitate women who were no longer allowed to work in licensed brothels, and the "prevention of immorality"41 Among the new invitees to those debates was Marguerite Thibert, the French socialist and feminist

36 Weindling, "The Politics of International Co-ordination," 96. See also: Angelique Richardson, Love and Eugenics in the Late Nineteenth Century. Rational Reproduction and the New Woman (New York, 2003).

37 Annex: Report presented by the Sub-commission sur les conditions de séjour des marins dans les port, by J. Havelock Wilson and T. Salveson. Venereal Diseases: Correspondence respecting Treatment of sailors in port, League of Nations Archives (hereafter LNA), 8A/8227/1525; "Amélioration des conditions de séjour des marins dans les ports," Genève, 1931, accessed December 29, 2016, http://staging.ilo.org/public/libdoc/ilo/1931/31Bo9_14 fren.pdf.

38 Report of the Special Body of Experts on Traffic in Women and Children (two parts), Geneva, League of Nations Advisory Committee on Traffic in Women and Children, 1927; League of Nations Commission of Enquiry into Traffic of Women and Children in the East—Report to the Council, Geneva, 1932.

39 Magaly Rodríguez García, "La Société des Nations face à la traite des femmes et au travail sexuel à l'échelle mondiale," Le Mouvement Social 241 (2012): 105-125.

40 League of Nations Advisory Committee on Traffic in Women and Children (hereafter "Committee"), Minutes of the Ninth Session, Eighth Meeting, Geneva, 5 April 1930, 49, LNA C.246M.121.1930.IV.

41 Miss Whitton, Canadian representative, Committee, Minutes of the Fifteenth Session, Fifth Meeting, Geneva, 22 April 1936, 10, LNA, CTFE/15th Session/PV.5. 
who, after 1931, led the ILO's Section on Conditions of Employment of Women and Children. ${ }^{42}$

The Great Depression and its impact on women's work did not pass unnoticed by the ILO. In particular, domestic work received much attention, as it constituted the largest occupation for women at the time. ${ }^{43}$ The League's anti-traffic committee also paid attention to that branch of labor, because its members had found sufficient evidence that domestic servants furnished a large proportion of prostitutes. The Belgian representative Isidore Maus had already in 1927 asked his colleagues to pay more attention to the "considerable influence of low wages on the development of prostitution," but not everyone seemed to agree. ${ }^{44}$ This was an issue that resurfaced in each annual meeting, yet no consensus was reached. According to the British delegate S.W. Harris, too much emphasis was laid on the connection between wages and prostitution $^{45}$ and in 1929, the French abolitionist Avril de Sainte-Croix informed the members of the committee that the letters she had received from British colleagues suggested that "poverty was not the only cause of prostitution, but that idleness, coquetry, greed and bad company also play a part."46 They all agreed, however, that the issue of wages paid to young women was part of a larger economic question, and that it needed to be studied in coordination with the ILO. Louis Varlez, ILO's representative in the League's anti-traffic committee during the 1920s, supported Maus' proposal to study the question of wages, but warned that it "covered an enormous field, of which the investigation would require hundreds of volumes." ${ }^{47}$ Nevertheless, he promised to give all his support to any investigation on the theme as long as it was clearly defined. To my knowledge, no joint study emerged from those discussions.

42 On Thibert, see: Françoise Thébaud, "Construire un espace européen ou construire un espace international. L'exemple de Marguerite Thibert (1886-1982)," in Les rôles transfrontaliers joués par les femmes en Europe, ed. Guyonne Leduc (Paris, 2012), 267-282; Françoise Thébaud, "Les femmes au BIт: l'exemple de Marguerite Thibert," in Femmes et relations internationales, eds. Jean-Marc Delaunay and Yves Denéchère (Paris, 2006), 177-187. I am thankful to Françoise Thébaud for providing me with these publications.

43 Eileen Boris and Jennifer N. Fish, "Decent Work for Domestics: Feminist Organizing, Worker Empowerment, and the ILO," in Towards a Global History of Domestic and Caregiving Workers, eds. Dirk Hoerder, Elise van Nederveen Meerkerk, and Silke Neunsinger (Leiden, 2015), 530-552.

44 Committee, Minutes of the Sixth Session, Third Meeting, 26 April 1927, 16, LNA C.338.M.113.1927.IV. Similar discussions took place within the feminist movement. See: Christine Machiels, Les féminismes et la prostitution (1860-1960) (Rennes, 2016), particularly the chapter on the feminist lobby within the League of Nations, 143-176.

45 Committee, Minutes of the Sixth Session, Third Meeting, 26 April 1927, 17.

46 Committee, Minutes of the Eight Session, Geneva, 19-27 April 1929, 116, LNA C.294. M.97.1929.IV.

47 Committee, Minutes of the Sixth Session, Third Meeting, 26 April 1927, 16. 
Thibert seemed more determined to tackle the problems faced by working women, but her conclusions on prostitution did not differ from the ideas of her abolitionist colleagues inside and outside the League. During a meeting of the League's anti-traffic committee in 1934, a discussion arose about the effects of unemployment and the economic crisis on women. The representative of the International Union of Catholic Women's Leagues, Ms. Lavielle, reported on an investigation conducted in various countries by Catholic women's associations and stated that "it was evident that unemployment, and even the inadequacy of women's earnings, constituted one of the factors of prostitution."48 Nevertheless, she emphasized that the union "was convinced that the demoralization of young people was due to deeper causes than those of an economic character." She added that only a few women had mentioned unemployment as the cause of prostitution, and believed that "the replies of prostitutes were often merely pretexts." In her view, many of them simply refused to work. Although the Polish delegate, Mrs. Grabinska, disagreed by arguing that unemployment "constituted a serious danger" for young women, the ILO representative chose the middle way. Thibert said that she had tried to study the subject, but that an analysis based on statistics had led to no satisfactory results. In her view, the initiatives undertaken by voluntary organizations were of great value to respond to "the particular evils caused by present circumstances."

All the participants in those debates perceived prostitution as an evil, not work. They understood work as something positive, which could keep men and women at a safe distance from an immoral life. Since the nineteenth century, voluntary associations had established non-profit employment bureaus and rescue homes where training and workrooms for women were organized. Yearly reports informed the League's anti-traffic committee of their continuous efforts to secure jobs and to "inculcate in young girls a love of work." ${ }^{49}$ As stated in one chapter authored by the ILO in the committee's 1939 study on the prevention of prostitution, the idea was to provide "protection by means of work." 50

48 This and the following quotes are taken from: Committee, Minutes of the Thirteen Session, Second Meeting, Geneva, 4 April 1934, 16-27, 26-27, LNA CTFE/13th Session/PV (Revised).

49 Committee, Minutes of the Fourteenth Session, Third Meeting, Geneva, 3 May 1935, 7, LNA CTFE/14th Session/PV.3.

5o This and the following quotes are taken from: "The moral protection of young women drawn up by the International Labour Office," in Prevention of Prostitution: A Study of Preventive Measures, Especially Those which Affect Minors (Geneva, League of Nations Advisory Committee on Social Questions, 15 May 1939), 6o-61, LNA, CQS/A/19(a). The report was published in 1943 and also contains a chapter by the renowned Danish eugenicist 
The ILO had come to the conclusion that although certain forms of employment (such as domestic service or jobs in bars, dance halls, and other public places) "may cause moral danger," a lack of occupation was no less risky. It also demanded attention for working conditions. Wages and the status of some occupations needed improvement to protect women against the "temptation to find a way out by taking up a shameful but profitable trade." Within the ILO, Thibert was making great efforts to improve domestic work, but admitted that progress was slow. In her view, "it was of the utmost importance that girls taking up domestic service should feel that they had a real vocation and should not be ashamed of their work." 51

Work was thus to be made attractive to women, but it needed to be monitored. The League's anti-traffic committee applauded the efforts of voluntary organizations, which sought cooperation with ministries of labor and private employment agencies to obtain not only working permits for foreign girls but also "moral guarantees" for jobs abroad. ${ }^{52}$ The ILO, too, promoted itself as a crucial partner for the task of supervising female labor. In its contribution to the League's study on the prevention of prostitution, the ILO's analysis focused on three measures: Regulation of placing operations, protection in the workplace, and protection of female workers during their spare time.

A measure for the regulation of job placement was adopted in 1933, when the International Labour Conference adopted an international convention to abolish all fee-charging employment agencies and to supervise non-profit bureaus working under the mask of philanthropy. Among the important provisions for the protection of women in the workplace were conventions on the minimum age for industrial and non-industrial employment. Supervision of employment in the entertainment industry, restaurants, and domestic service in particular called for greater attention. Only a few countries (e.g. France) had established inspectorates to intervene in cases where "a girl's morals may be endangered by the employment provided for her."53

With regard to the protection of young women outside of working hours and during holidays, the ILO had to admit that legislation on the subject was restricted. Since spare time did not belong to the employer-employee

Dr. Tage Kemp, on the "physical and psychological causes of prostitution and the means of combatting them."

51 Committee, Minutes of the Fifteenth Session, Fifth Meeting, 22 April 1936, 4, LNA CTFE/ 15th Session/PV.5.

$5^{2}$ Committee, Minutes of the Third Session, Geneva, 7-11 April 1924, 83, LNA C.217. M.71.1924.IV.

53 The following quotes and information are taken from: "The moral protection of young women drawn up by the International Labour Office," $60-61,70-73$. 
relationship, the recreation activities organized by charitable associations were of crucial importance. The ILO found four types of private initiatives that at the time of writing (1939) were apparently worth mentioning: Youth hostels, Christian workers' organizations, social service or adult education associations, and institutions organized by political parties, such as the socialist women's groups in Belgium and the Hitler Youth in Germany. Among the activities organized by public authorities, the ILO took the German, Italian, and Soviet tourist services as examples. ${ }^{54}$ Obviously, the ILO explained, the objective of all these initiatives was not merely recreational. The educational aim was to teach "young persons of both sexes to live in normal, healthy friendship."

Health concerns remained a priority for the ILO, which explains the repeated call for increased cooperation between the League's anti-traffic committee and the LNHO. In addition, the UIPV's leader, J.A. Cavaillon, was in favor of coordinated action between the Geneva specialized organizations, and agreed to contribute with a chapter on the reduction of demand for the League's study into the prevention of prostitution-a Swedish model avant la lettre. ${ }^{55}$ In the immediate post-war period, the ILO agreed to join hands with the LNHO's successor, the World Health Organization (wHo). As the role played by private associations diminished, the ILO/WHO campaigns against sTDs became more technical and based on purely medical foundations. ${ }^{56}$

\subsection{After 1976}

As the previous section demonstrates, the ILo's early views on prostitution were neither static nor monolithic, and the post-war period shows no difference. Further archival research is required in order to find out whether the ILO considered prostitution directly (that is, not indirectly, such as within the Joint ILO/WHo Committees on the Hygiene of Seafarers, and on Occupational Health) in the 1950s and 196os. To my knowledge, the theme returned to the ILO agenda in the mid-1970s, when an Office for Women Workers' Questions was set up by the director-general. During the World Employment Conference of 1976, special attention was paid to the working and living conditions of rural

54 In Europe, leisure time became increasingly formalized, regularized, and institutionalized from the eighteenth century onward. During the interwar period, the organization of leisure was a powerful control mechanism of authoritarian regimes. For analyses of the organization of leisure time in Italy and Germany, see Victoria de Grazia, The Culture of Consent: Mass Organisation of Leisure in Fascist Italy (Cambridge, 2002); Shelley Baranowski, Strength Through Joy: Consumerism and Mass Tourism in the Third Reich (Cambridge, 2007).

55 J.A. Cavaillon, "Reduction of demand," in Prevention of prostitution, LNA CQS/A/19(c).

$5^{6}$ Weindling, "The Politics of International Co-ordination," 102. 
women in developing countries. ${ }^{57}$ The establishment of U.S. military bases in Thailand in the mid-196os led to a mushrooming of "go-go" bars and to the growth of the phenomenon of "hired wives"-many of them recruited from rural areas-for American servicemen. ${ }^{58}$ In the aftermath of the American departure, the development of erotic tourism attracted the attention of international organizations. In the late 1970s, the ILO's "Programme on Rural Women" focused first on the involvement of young women as masseuses in the sex trade of Bangkok.

This was perhaps the first time the ILO- or at least one of its branchesdescribed prostitution as a form of work. Interestingly, the idea of prostitution as work entered the ILO via its Asian connections. In his preface to the study, Dharam Ghai (head of research at the ILO World Employment Programme) praised the investigation on Thai masseuses as "an important contribution to understanding a highly publicised but under-researched dimension of women's work."59 Its author, Pasuk Phongpaichit (a Thai Ph.D. in economy from Cambridge University) delivered an analysis based on fundamental details obtained from in-depth interviews with fifty masseuses. She focused on the causes of migration, the women's experiences, and the impact on their families once they left the countryside. Contrary to previous studies on prostitution produced in Geneva, Phongpaichit's research stressed the economic motives of the women involved and the negative impact of the Thai market economy on rural households. The wide income gap between urban and rural landscapes provided the setting for migration. She concluded:

It is within an economic system structured in this particular way that the actions of the migrant girls must be understood. They were not fleeing from a family background or rural society which oppressed women in conventional ways. Rather they were engaging in an entrepreneurial move designed to sustain the family units of a rural economy which was coming under increasing pressure ... The returns available in this particular business, rather than in other business accessible to an unskilled

57 "Activities of the ILO, 1976. Report of the Director-General (Part 2)," International Labour Office, Geneva, 1977, 68-69, accessed January 5, 2017, http://www.ilo.org/public/ portugue/region/eurpro/lisbon/pdf/o9383_1977_63_part2.pdf.

$5^{8}$ Leslie Ann Jeffrey, Sex and Borders: Gender, National Identity and Prostitution Policy in Thailand (British Columbia, 2007).

59 Pasuk Phongpaichit, "Rural Women of Thailand: From Peasant Girls to Bangkok Masseuses," International Labour Organisation, World Employment Programme ResearchWorking Paper, November 1980, iii, accessed January 5, 2017, http://www.ilo.org/public/ libdoc/ilo/1980/8oBog_876_engl.pdf?gathStatIcon=true. 
and uneducated person, had a powerful effect on their choices. Our survey clearly showed that the girls felt they were making a perfectly rational decision within the context of their particular social and economic situation. ${ }^{60}$

In subsequent decades, the blooming of sex tourism and the fear of the spread of HIV infection strengthened the ILO's interest in the issue. Lin Lim, ILO Senior Specialist on Women Workers' Questions for Asia and the Pacific, took up the subject in the 199os and coordinated the work for an edited volume that further antagonized the rivalling camps within the prostitution debate. It is not clear whether or to what extent Lin Lim was influenced by the sex workers' movement. However, the book she helped to produce shows many commonalities not only with the research conducted by Pasuk Phongpaichit, but also with the conclusions drawn by activists and scholars who called for the redefinition of prostitution as work. The study examines the social and economic factors that influenced the growth of the sex industry in four Southeast Asian countries (Indonesia, Malaysia, the Philippines, and Thailand). It emphasizes the economic bases of prostitution and stresses the material and non-material advantages it provided to young (uneducated) women: Higher wages, flexibility, and increased mobility. ${ }^{61}$

The ILO authors argued that since commercial sex had developed into a full-blown industry providing employment to millions of people worldwide, it should be recognized as an economic sector. In their view, the official recognition of the sex industry would imply the maintenance of records and statistics, which would in turn be beneficial for the preparation of development plans and government budgets, as well as for securing accurate assessments of the health impact and general working conditions in the sector. The study made a clear distinction between adult and child prostitution, the latter being described as a human rights violation and an intolerable form of labor to be eradicated. In her introduction to the report, Lin Lim acknowledged the "wide range of circumstances of those in prostitution,"62 but grouped adults engaged in the sex trade into three categories:

6o Phongpaichit, "Rural Women of Thailand," 141-142. For a comparative analysis that mentions "filial duty" as strong motivation for engagement in prostitution, see: Heerma van Voss, "The Worst Class of Workers': Migration, Labor Relations and Living Strategies of Prostitutes Around 19oo."

61 Lin Leam Lim, ed., The Sex Sector: The Economic and Social Bases of Prostitution in Southeast Asia (Geneva, 1998).

62 This and the following quotes are taken from: Lin Leam Lim, "The economic and social bases of prostitution in Southeast Asia," in Lin Leam Lim, The Sex Sector, 2-3. 
Some adults make a relatively 'free' personal choice or choose to work as prostitutes as their right to sexual liberation; others 'choose' sex work because of economic pressures or because there are no better-paying alternatives; and yet others are overtly pressured by third parties in the form of deception, violence and/or debt bondage.

Hence she concluded that "in the case of adults it may be possible to make a distinction between 'voluntary' prostitution and prostitution through coercion." A harsh criticism of the abolitionist approach was implicit in her analysis. "Many current studies," she wrote, "highlight the pathetic stories of individual prostitutes, especially of women and children deceived or coerced into the sector. Such an approach tends to sensationalize the issues and to evoke moralistic, rather than practical, responses."

Lin Lim's stance gained her the praise of (feminist) advocates of the sex work perspective, ${ }^{63}$ but it also drew a rebuke from the abolitionist camp. In an essay published by the Coalition Against Trafficking in Women, shortly after the publication of Lin Lim's book, the radical feminist Janice Raymond deplored that the ILO had "become the latest and most questionable group urging acceptance of the sex industry," because legalization of the sex sector necessarily implied a "recognition of prostitution and related forms of sexual entertainment as sex work." ${ }^{44}$ However, in the book's preface, Lin Lim explicitly stated that it was "outside the purview of the ILO to take a position on whether prostitution should be legalized." 65 When she received the 1998 International Nike Award at the Frankfurt Book Fair in Germany, Lin Lim reiterated that "recognition of prostitution as an economic sector does not mean that the ILO is calling for the legalization of prostitution." ${ }^{66}$ Raymond took some abstracts from the book to criticize Lin Lim's alleged call for the recognition of prostitution as "a

63 See for example, Laura María Agustín and Jo Weldon, "The Sex Sector: A Victory for Diversity," Global Reproductive Rights Newsletter 66/67 (2003): 31-34, accessed January 5, 2017, http://www.nswp.org/sites/nswp.org/files/The\%2oSex\%2oSector\%20-\%20\%20A\%20 Victory\%2ofor\%2oDiversity.pdf.

64 Janice G. Raymond, "Legitimating Prostitution as Sex Work: UN Labour Organization (ILO) Calls for Recognition of the Sex Industry," Coalition Against Trafficking in Women, July 1999, accessed January 6, 2017, http://www.catwinternational.org/Home/Article/61 -legitimating-prostitution-as-sex-work-un-labour-organization-ilo-calls-for-recognition -of-the-sex-industry. See also: Janice G. Raymond, Not A Choice, Not A Job: Exposing the Myths about Prostitution and the Global Sex Trade (Washington, DC, 2013).

65 Lin Leam Lim, "Preface", in Lim, The Sex Sector, v.

66 "ILo Report on the Sex Sector Receives Prestigious Prize at Frankfurt Book Fair," International Labour Organization, 10 October 1998, accessed January 6, 2017, http://www.ilo.org/ global/about-the-ilo/newsroom/news/WCMS_007999/lang--en/index.htm\#N_1_. 
legal occupation,"67 but Lin Lim's quote in its entirety shows a more nuanced stance:

In the case of adults, prostitution could be viewed as a matter of personal choice and a form of work, in which case the policy issues are mainly concerned with whether prostitution should be recognized as a legal occupation with protection under labour law and social security and health regulations. ${ }^{68}$

In the last chapter of the book, Lin Lim provided "some policy considerations" and explained the different possible legal approaches and the pros and cons of criminalization/prohibition, legalization, and decriminalization of prostitutes. ${ }^{69}$ In its public communication, the ILO insisted that, "it is for countries themselves to decide on the legal stance to adopt."70

\subsection{Recent Decades ${ }^{71}$}

National responsibility continues to be the ILO's official position on prostitution. In the new millennium, the entry point into the debate on commercial sex became HIV/AIDs prevention. The ILO's involvement with the issue had already started in the late 1980s, when it held a joint consultation with the WHO on AIDS and the workplace, but the ILO Programme on HIV/AIDS (ILO/AIDS) was formally established in November 2000. ${ }^{72}$ In 2010, the ILO Recommendation (No. 20o) concerning HIV and AIDS and the World of Work was adopted at the 99th International Labour Conference (ILC) with the aim of strengthening national policies and programs to combat the pandemic. ${ }^{73}$

67 Raymond, "Legitimating Prostitution as Sex Work," point 7 of section "Arguments and Answers."

68 Lim, "The economic and social bases of prostitution in Southeast Asia," 2.

69 Lin Leam Lim, "Whither the Sex Sector? Some Policy Considerations," in Lim, The Sex Sector, 206-222.

$70 \quad$ "ILO Report on the Sex Sector Receives Prestigious Prize."

71 I am grateful to Dorothea Hoehtker from the ILo Century Project, and Richard Howard, Director of the ILO Country Office for Nepal, for the information on the ILO initiatives to combat HIV/AIDS and forced labor, and the exchange of views on the recent ILO position on prostitution. My attempts to talk to Beatee Andrees, former head of the ILo Special Action to Combat Forced Labour, on the issue of voluntary vs. forced prostitution led to no result.

72 For an analysis of the relationship between labor and the spread of HIV infection, as well as the response to the pandemic by the powerful International Transport Federation, see: Michel Pigenet, "Le VIH-Sida, nouveau terrain d'intervention syndicale dans les transports internationaux," Le Mouvement Social 241, no. 4 (2012): 185-203.

73 “ILOAIDS' History," International Labour Organization, accessed January 6, 2017, http:// www.ilo.org/aids/Aboutus/WCMS_DOC_AIDS_ABO_BCK_EN/lang--en/index.htm. 
During the debates within the ILC's Committee on HIV/AIDS, a government member from the Netherlands proposed an amendment to the recommendation's draft to insert an extra clause- - (d) sex workers"-in paragraph 2, which described the instrument's scope. Paragraphs 2(a) and 2(c) listed the categories of workers and services covered by the recommendation: "Persons in any employment or occupation; those in training, including interns and apprentices; volunteers; job seekers and job applicants; laid-off and suspended workers; armed forces and uniformed services." 74 The Dutch representative argued that it was difficult to develop effective programs for an important target group such as sex workers if they remained unrecognized. The worker's representative, J. Sithole (Swaziland), supported the amendment, but governmental representatives were divided on the issue. The French representative stated that his government "could not support the amendment, since sex workers were not a legal category of workers. ${ }^{\prime 75}$ All the members of the committee agreed that an explicit reference to sex workers was unnecessary, since they could be considered to be covered by Paragraph 2(b): "all sectors of economic activity, including the private and public sectors and the formal and informal economies." The Dutch delegate withdrew the amendment on the understanding that sex workers were also included in the general description of Paragraph 2(a): "all workers working under all forms or arrangements, and at all workplaces."

The ILO/AIDS program focuses on the factors that enhance the risks of HIV infection, and that pose barriers to access to treatment facilities. It emphasizes the vulnerabilities of sex workers and aims at "reducing stigma and discrimination, promoting economic empowerment of women and men and addressing gender dimensions." ${ }^{76}$ It does not advocate launching an international convention on sex work, but follows a bottom-up approach to promote "decent work" in the sex industry. ${ }^{77}$ Richard Howard, former ILO senior specialist on HIV and AIDS in the Asia-Pacific region, described Recommendation 200 as "an intermediary strategy for addressing the working conditions and improved

74 "Recommendation concerning HIV and AIDS and the World of Work, 2010 (No. 200)," (Geneva, 2010), 3, accessed January 6, 2017, http://www.ilo.org/wcmsp5/groups/public/ ---ed_protect/---protrav/---ilo_aids/documents/normativeinstrument/wcms_142706.pdf.

75 "Fifth item on the agenda: HIV/AIDS and the world of work," Report of the Committee on HIV/AIDS, International Labour Conference, 99th Session, Geneva, June 2010, 27-28, accessed January 10, 2017, http://www.nswp.org/sites/nswp.org/files/ILO\%2oReport\%20 of $\% 20$ the $\% 20$ Committee $\% 200$ \%20HIV\%20AIDS.pdf.

76 "HIV and work. Getting to Zero through the world of work."

77 "Viet Nam's Sex Industry-A Labour Rights Perspective," ILo Country Office for Viet Nam, 16 September 2016, accessed January 11, 2017, http://www.ilo.org/wcmsp5/groups/public/ ---asia/---ro-bangkok/---ilo-hanoi/documents/publication/wcms_524918.pdf. 
HIV prevention, treatment and services for sex workers." ${ }^{78}$ In his view, the role of the ILO is to facilitate partnerships with trade unions. During the XIX International Aids Conference of 2012, he mentioned Cambodia as a model.

During the same event, Marijke Wijnroks, the Netherlands Special Ambassador for HIV/AIDS and Sexual Reproductive Health, described the Dutch approach to prostitution. She explained that sex work is legal in her country and stressed the government's support of international programs aimed at the protection of sex workers' rights. However, she added a critical note on a recent evolution that is also being felt in the Netherlands:

Over the last couple of years we've seen an increasing tendency to more strictly regulate sex work in an attempt to control human trafficking ... This is doomed to fail because sex work and human trafficking are two very different issues, and should not be confused. Still, this is happening.

Indeed, the issue of trafficking returned to the agendas of national governments and international organizations at the end of the twentieth century. Within the ILO, the starting point for discussing forced prostitution was the observation made by the Osaka Fu Special English Teachers' Union (OFSET) in 1995, on the Japanese violation of the Forced Labour Convention during the years prior to and during the Second World War. The allegations referred to the so-called "comfort women," and OFSET asked for appropriate compensations to be made. The ILo's Committee of Experts ruled that Japan's system of military sexual slavery violated the Forced Labour Convention (No. 29) of 1930, but that it did not have the power to order the relief sought. ${ }^{79}$ By the turn of the century, the ILo had created its Special Action Programme to Combat Forced Labour, and has subsequently contributed to the conceptual confusion in

78 This and the following quotes are taken from: "IAC Washington/Kolkata joint session: The Oldest Profession: is Sex Work, Work?” xix International Aids Conference, 22-27 July 2012, accessed January 10, 2017, http://www.nswp.org/news/iac-washington kolkata-joint-session-the-oldest-profession-sex-work-work.

79 Observation (CEACR) — adopted 1996, published 85th ILC Session (1997): Forced Labour Convention, 1930 (No. 29) 一Japan (Ratification: 1932), accessed January 10, 2017, http:// www.ilo.org/dyn/normlex/en/f?p=1000:13100:0::NO:1310o:P13100_COMMENT_ID:2152098. See also: Sayoko Yoneda, "Sexual and Racial Discrimination: An Historical Inquiry into the Japanese Military's 'Comfort' Women System of Enforced Prostitution," in Nation, Empire, Colony: Historicizing Gender and Race, eds. Ruth Roach Pierson and Napur Chaudhuri (Bloomington, 1998), 237-250; Heisoo Shin, "Seeking Justice, Honour and Dignity: Movement for the Victims of Japanese Military Sexual Slavery," in Global Society 2011: Globality and the Absence of Justice, eds. Helmut Anheir et al. (New York, 2011), 14-28. 
international law and to the conflation of human trafficking and prostitution. ${ }^{80}$ In a recent study on sexual exploitation and prostitution requested by the European Parliament's Committee on Women's Rights and Gender Equality, the authors stated that international law provisions such as those provided by the ILO point to the thin dividing line between prostitution and trafficking. ${ }^{81}$

Article 2(1) of the 1930 convention defines forced or compulsory labor as "all work or service which is exacted from any person under the menace of any penalty and for which the said person has not offered himself voluntarily," 82 yet on its website, the ILO introduces confusion. "The forced labour definition encompasses," the website states:

Traditional practices of forced labour, such as vestiges of slavery or slavery-like practices, and various forms of debt bondage, as well as new forms of forced labour that have emerged in recent decades, such as 'human trafficking,' also called 'modern slavery', to shed light on working and living conditions contrary to human dignity. ${ }^{83}$

Hence, the ILo has expanded its definition of the term "forced labour" to include "modern slavery" and "human trafficking," even though the former has no legal standing and the latter is, in legal terms, not a form of (labor) exploitation but a process. ${ }^{84}$

8o Magaly Rodríguez García, "On the Legal Boundaries of Coerced Labor," in On Coerced Labor: Work and Compulsion after Chattel Slavery, eds. Marcel van der Linden and Magaly Rodríguez García (Leiden, 2016), 11-29.

81 Erika Schulze et al., "Sexual Exploitation and Prostitution and its Impact on Gender Equality" (Brussels, 2014), 16, accessed January 10, 2017, http://www.europarl.europa.eu/ RegData/etudes/etudes/join/2014/493040/IPOL-FEMM_ET(2014)493040_EN.pdf. This report lay at the basis of the EU Resolution approved in February 2014, which calls EU states to criminalize clients of prostitution.

82 "Forced Labour Convention, 1930 (No. 29)," International Labour Organization, accessed January 10, 2017, http://www.ilo.org/dyn/normlex/en/f?p=NORMLEXPUB:12100:0::NO ::P12100_ILO_CODE:Co29.

83 "What is forced labour, modern slavery and human trafficking," International Labour Organization, accessed January 10, 2017, http://www.ilo.org/global/topics/forced-labour/ definition/lang--en/index.htm.

84 Human trafficking only came to be defined in the 2000 UN Protocol to "Prevent, Suppress and Punish Trafficking in Persons, Specially Women and Children," accessed January 10, 2017, http://www.ohchr.org/EN/ProfessionalInterest/Pages/ProtocolTraffickingInPersons .aspx. Following the definition described in Art. 3(a), human trafficking is understood as a process which consists of three elements: A method (recruitment, transportation, transfer, harbouring, or receipt of persons), a means (threats, use of force, coercion, abduction, 
This broad interpretation of forced labor reifies the mental binaries of victim/perpetrator without taking into account the fluidity and complexity of labor relationships in the sex industry. ${ }^{85}$ It negates the agency of sex workers, who often "respond to push factors ... rather than the pull factor of trafficker enticement." 86 It also simplifies labor arrangements that often result in both progress and subjugation, improving workers' economic opportunities and at the same time submitting them to exploitative working conditions. Akin to analyses and international tools to combat trafficking during the early twentieth century, the ILO instruments on forced labor stress the danger presented to women and girls, and establish a dichotomy between forced sexual exploitation and forced labor exploitation. ${ }^{87}$

Siddharth Kara is an important advisor to the ILo's program against forced labor. He is a well-known anti-trafficking activist, who promotes the criminalization of clients, the destruction of the economic basis of the industry that produces "sex slaves," and the establishment of "community vigilance committees" to rescue trafficked women and girls. ${ }^{88}$ The ILO's 2014 publication on the economics of forced labor relies heavily on Kara's methodology. ${ }^{89}$ In spite of the harsh criticism of his statistical methods, qualitative analysis and proposed solutions, ${ }^{90}$ his affiliation to the Harvard Kennedy School as Fellow of

fraud, deception, abuse of power or of a position of vulnerability, or of the giving or receiving of payments or benefits to achieve consent), and a purpose (exploitation).

85 Kimberly Kay Hoang and Rhacel Salazar Parreñas, "Introduction," in Human Trafficking Reconsidered. Rethinking the Problem, Envisioning New Solutions, eds. Kimberly Kay Hoang and Rhacel Salazar Parreñas (New York, 2014), 1-18, 7-9.

86 Ronald Weitzer, "New Directions in Research on Human Trafficking," The ANNALS of the American Academy of Political and Social Science 653, no. 6 (2014): 6-24, 16.

87 Eileen Boris and Heather Berg, "Protecting Virtue, Erasing Labor: Historical Responses to Trafficking," in Hoang and Salazar Parreñas, Human Trafficking Reconsidered, 19-29. In 2014, the International Labour Conference approved the Protocol to the Forced Labour Convention, 1930, and the Forced Labour (Supplementary Measures) Recommendation (No. 203).

88 Siddharth Kara, Sex Trafficking. Inside the Business of Modern Slavery (New York, 2009).

89 "Profits and Poverty: The Economics of Forced Labour," International Labor Organization (Geneva, 2014), accessed January 10, 2017, http://www.ilo.org/wcmsp5/groups/public/--ed_norm/---declaration/documents/publication/wcms_243391.pdf.

9o Ann Jordan, "Sex Trafficking: The Abolitionist Fallacy," Foreign Policy in Focus, 18 March 2009, accessed January 10, 2017, http://fpif.org/sex_trafficking_the_abolitionist_fallacy/; Laura Agustín, "Review of Kara, Siddharth, Sex Trafficking: Inside the Business of Modern Slavery," H-LatAm, H-Net Reviews, February 2012, accessed January 10, 2017, http://www .h-net.org/reviews/showpdf.php?id=35320. In his review on Kara's campaigning book on sex trafficking and modern slavery, Jonathan Birchall ("Sex Trafficking," Financial Times, 24January 2009) asked himself: "So would Kara's 'community vigilance committees' working with 'the moral rigour of tens of thousands of committed citizens' be seen by the sex 
the Carr Center for Human Rights Policy has accorded Kara's work and abolitionist campaigns a standing of scientific authority.

The popular language of trafficking is used by abolitionist activists who understand prostitution as gender-based violence, as well as by public authorities that present themselves as defenders of human rights to justify stringent migration policies and to arbitrarily remove people or businesses deemed undesirable. It is therefore doubtful whether the ILO campaigns against forced labor will boost the efforts of ILO/AIDS to improve the working and living conditions of sex workers.

"The issue of prostitution has always been controversial," wrote Lin Lim in the first lines of the preface to the ILO's publication on the sex sector in Southeast Asia. Almost one hundred years after its foundation, the ILO still has difficulties in positioning itself in the prostitution debate. ${ }^{91}$ Instead of taking a clear and unified stance on the issue, it has opted for decentralization and for the development of programs aimed at tackling problems linked to prostitution: STDs and trafficking. Further research-particularly of unpublished material-is needed in order to analyze whether the members of the various ILO's sections competed or cooperated with each other, and to gauge the extent to which advocates of the sex-work perspective and the abolitionist approach influenced the ILO's health and forced labor programs. Judging from its published sources, the ILO seems to have become a battleground for competing views on commercial sex.

The ILO's health branch has been more inclined to take a pragmatic approach. During the interwar period, it supported the hegemonic view on prostitution, but from the 1950s onward, and particularly after the increased AIDS incidence through the 1980 s, the ILO programs became focused on treatment and prevention, rather than on the morality of sex work. Learning - perhaps inadvertently-from the controversy caused by the publication of the sexsector book, the ILO/AIDS program's staff have adopted a more gradual strategy. Instead of proposing measures that could be interpreted as a call for the legalization of prostitution, they have concentrated on the development of national HIV/AIDS workplace legislation and policies, the expansion of social

trade as allies and defenders, seeking to eradicate violence and compulsion, or as moralist enemies of the sex trade itself?"

91 Skype conversation with Richard Howard, Brussels-Lalitpur (Nepal), 12 January 2017. 
protection for people affected by HIV and AIDS, and the reduction of workers' vulnerability to HIV through economic empowerment. While their activities around sex workers do not feature prominently on the website, it seems that they are primarily concerned with the promotion of grass-roots initiatives to improve knowledge of legal rights and to forge partnerships with authorities and trade unions. Whether this strategy will lead to the integration of sex workers in national trade unions in more countries than is now the case, and whether such recognition will translate into the decriminalization or legalization of sex work, will depend on two factors: The strength of the abolitionist movement, and more importantly, the resilience of sex workers' organizations.

In spite of the growth of the sex workers' movement during recent decades, a unified voice has not yet been achieved. While the best-organized groups lobby for legalization, others advocate only for decriminalization. ${ }^{92}$ Some social organizations active in the Global North stress the risks of legalization for migrant sex workers who have no residency permits. This is one of the main criticisms of the Dutch system, which created a legal framework that only applies to EU subjects. Some sex workers also point at the disadvantages of both schemes. While some dislike the idea of having to do paperwork and pay taxes, others complain about the increased competition from more laissez-faire commercial sex markets. In Zimbabwe, for example, after the sex trade became decriminalized in 2015 a flood of women joined it, driving the prices down. ${ }^{93}$ During conversations with sex workers, I have noticed in some of them a slight temptation to adopt the human trafficking discourse in an attempt to reduce the flow of migrants who may push locals out of business or lead to a worsening of working conditions. Furthermore, the persistent stigma results in sex workers' continued hesitance to become involved in public manifestations or to provide first-hand testimonies that would support comprehensive analyses of prostitution.

These are all thorny issues that make the development of strong and unified sex workers' movement difficult. As long as this does not occur, the universal recognition of prostitution as work will remain utopia.

92 See e.g. Juno Mac, "The laws that sex workers really want," TED-talk 13 June 2016, accessed September 19, 2017, https://www.ted.com/talks/juno_mac_the_laws_that_sex _workers_really_want.

"Less stigma, more competition," The Economist, 7-13 January 2017, 26. 